\title{
Peran mediasi return on asset pada hubungan debt to equity ratio dan total asset turnover terhadap price to book value: Investigasi pada sektor Pertambangan Batu Bara
}

\author{
Muliyati $^{1}$, Fitra Mardiana ${ }^{2}$ \\ ${ }^{1 \& 2}$ Universitas Wijaya Putra Surabaya \\ liachi625@gmail.com
}

\begin{abstract}
The purpose of this study is to explore the influence of debt to equity ratio (DER) and total asset turnover (TATO) on price to book value (PBV), and the role of return on assets (ROA) in mediating independent constructive relationships on dependents. The population in this study is as many as 24 Coal Mining companies, after being sorted based on sample criteria using purposive sampling techniques, there are 9 companies suitable to be sampled in this study. The analysis method used is Path Analysis by using SPSS version 21. The results of the study obtained that directly DER has no significant effect on ROA, while TATO has a significant effect on ROA. DER and TATO variables have no significant effect on PBV. While the results of indirect data analysis, ROA is not able to mediate the relationship between $\mathrm{DER}$ to $\mathrm{PBV}$, and indirectly $\mathrm{ROA}$ is able to mediate the relationship between TATO to PBV.
\end{abstract}

Keywords: Debt to equity ratio (DER), total asset turnover (TATO), return on asset (ROA), dan price to book value (PBV), path analysis.

\begin{abstract}
Abstrak: Tujuan studi ini adalah untuk mengeksplorasi pengaruh debt to equity ratio (DER) dan total asset turnover (TATO) terhadap price to book value (PBV), dan peran dari return on asset (ROA) dalam memediasi hubungan konstruk independen pada dependen. Populasi pada studi ini yaitu sebanyak 24 perusahaan Pertambangan Batu Bara, setelah disortir berdasarkan kriteria sampel dengan menggunakan teknik purposive sampling maka terdapat 9 perusahaan yang cocok untuk menjadi sampel dalam studi ini. Metode analisis yang digunakan adalah Path Analysis dengan menggunakan SPSS versi 21. Hasil studi diperoleh bahwa secara langsung DER berpengaruh tidak signifikan terhadap ROA, sedangkan TATO berpengaruh signifikan terhadap ROA. Variabel DER dan TATO berpengaruh tidak signifikan terhadap PBV. Sedangkan hasil analisis data secara tidak langsung, ROA tidak mampu memediasi hubungan antara DER terhadap PBV dan secara tidak langsung ROA mampu memediasi hubungan antara TATO terhadap PBV.
\end{abstract}

Kata Kunci: Debt to equity ratio (DER), total asset turnover (TATO), return on asset (ROA), dan price to book value (PBV), path analysis. 


\section{PENDAHULUAN}

Tujuan manajemen perusahaan adalah memaksimalkan nilai kekayaan para pemegang saham (Harmono, 2015). Di dalam rencana untuk mencapai itu semua, perusahaan mencoba untuk senantiasa meningkatkan harga saham perusahaan. Semakin tinggi price-book value (PBV), semakin berhasil perusahaan dalam menciptakan nilai dan kemakmuran pemiliknya. Menurut (Barney, 1991) "semakin besar nilai PBV maka semakin tinggi perusahaan dinilai oleh investor relatifnya dibandingkan dengan dana yang telah ditanamkan pada perusahaan tersebut. "Semakin baik kinerja keuangan suatu perusahaan, semakin baik pula nilai perusahaannya." Semakin tinggi nilai perusahaan, semakin tinggi return yang diperoleh, dan semakin tinggi return saham maka semakin sejahtera pemegang saham. Keputusan keuangan yang diambil oleh manajer keuangan dimaksudkan untuk meningkatkan kesejahteraan pemilik perusahaan yang ditunjukkan dengan meningkatnya nilai perusahaan (Thakur dan Workman, 2016). Menurut Shil (1997) terdapat beberapa faktor yang dapat mempengaruhi kemampuan perusahaan dalam memaksimalkan price-book value salah satunya adalah profitabilitas.

Profitabilitas merupakan rasio untuk menilai kemampuan perusahaan dalam mencari keuntungan atau laba dalam suatu periode tertentu, proksi yang biasanya digunakan untuk mengukur tingkat profitabilitas perusahaan yaitu Return On Asset (ROA) (Kasmir, 2014). Peningkatan ROA pada perusahaan menunjukkan bahwa kinerja dan prospek sebuah perusahaan semakin baik, sebab memiliki potensi keuntungan yang diperoleh oleh perusahaan tersebut. Faktor yang lain yang dapat dipertimbangkan dan berpengaruh terhadap price-book value adalah Debt to Equity Ratio dan Total Asset Turnover (TATO). Total Asset Turnover (TATO) adalah salah satu rasio aktivitas yang merupakan hasil bagi dari penjualan dengan total aset. Sedangkan, Kasmir (2014) menganggap tentang Debt to Equity Ratio merupakan rasio yang digunakan untuk menilai utang dengan ekuitas. Rasio ini dicari dengan membandingkan antara seluruh utang, termasuk utang lancar dengan seluruh ekuitas. Beberapa faktor yang dapat menjadi prediktor dan mediator tersebut telah dianggap penting dalam menunjang terhadap terciptanya price-book value sebagai upaya perusahaan dalam menarik investor dari luar dan menggapai tujuannya (Syardiana et al., 2015).

Adapun alasan menjadikan Perusahaan Sektor Pertambangan Batubara sebagai objek studi karena pada tahun 2015 merupakan tahun penuh tantangan bagi sektor pertambangan. Adanya penurunan komoditas dibandingkan dengan tahun sebelumnya mendorong perusahaan pertambangan harus berupaya keras meningkatkan produktivitas, beberapa diantaranya berjuang untuk bertahan, diikuti dengan pelepasan aset atau penutupan usaha. Selain itu, para pemegang saham bersikeras untuk berfokus pada jangka pendek, yang berdampak pada ketersediaan modal untuk diinvestasikan dan mengakibatkan terbatasnya opsi pertumbuhan. 


\section{TINJAUAN TEORITIS}

\section{Pengaruh DER terhadap ROA}

Debt to Equity rasio merupakan salah satu rasio solvabilitas. Rasio solvabilitas merupakan rasio yang digunakan untuk mengukur sejauh mana aset perusahaan dibiayai dengan hutang. Perusahaan yang pendanaannya lebih banyak bersumber dari hutang akan menerima manfaat berupa pengurangan bunga hutang pada perhitungan penghasilan kena pajak, sehingga memperkecil proporsi beban pajak sehingga proporsi laba bersih menjadi lebih besar atau tingkat profitabilitasnya semakin tinggi (Sartono, 2014). Asumsi ini didukung oleh hasil studi Lindayani dan Dewi (2016) dan studi yang dilakukan oleh Marusya dan Magantar (2016) yang menyatakan bahwa Debt to Equity Ratio (DER) berpengaruh positif dan signifikan terhadapReturn on Asset (ROA).

H1: DER berpengaruh signifikan terhadap ROA.

\section{Pengaruh TATO terhadap ROA}

Total Asset Turnover digunakan untuk mengukur kemampuan perputaran seluruh aset yang dimiliki oleh perusahaan. Untuk dapat mencapai nilai ROA yang tinggi, maka aset yang dimiliki oleh perusahaan harus mempunyai perputaran yang tinggi pula. Semakin besar total asset turnover, akan semakin baik karena berarti semakin efisien seluruh aktiva yang digunakan untuk menunjang kegiatan penjualan (Ang, 1997). ROA yang meningkat dipengaruhi oleh total asset turnover. Brigham dan Houston (2001). Asumsi ini didukung oleh studi Sutrisno dan Yulianeu (2015) juga studi Satriya dan Wahyudi (2017) yang menyatakan bahwa Total Asset Turnover (TATO) berpengaruh positif signifikan terhadap ROA.

H2: TATO berpengaruh signifikan terhadap ROA.

\section{Pengaruh DER terhadap PBV}

Debt to Equity Ratio (DER) menggambarkan perbandingan antara total hutang dengan total ekuitas yang dimiliki oleh perusahaan. Semakin tinggi nilai DER maka, akan tinggi pula beban bunga yang ditanggung oleh perusahaan. Namun rasio ini juga dapat memberikan kesempatan kepada perusahaan untuk berekspansi, sehingga dapat meningkatkan jumlah laba perusahaan dan pada akhirnya akan memberikan pengaruh positif terhadap rasio profitabilitas dan nilai perusahaan pun juga akan meningkat. Hutang suatu perusahaan dianggap investor sebagai sinyal positif bagi perusahaan (Brigham, 2004). Asumsi ini didukung oleh studi Misran dan Chabachib dan Lestari (2017) juga hasil studi Pratama dan Wiksuana (2016) yang menyatakan bahwa DER berpengaruh positif dan signifikan terhadap Price to Book Value.

H3: DER berpengaruh signifikan terhadap PBV. 


\section{Pengaruh TATO terhadap PBV}

Menurut Weston dan Brigham (2010), Total Assets Turnover adalah Rasio aktivitas yang digunakan untuk mengukur sampai seberapa besar efektivitas perusahaan dalam menggunakan sumber daya yang berupa asset. Apabila rasio rendah itu merupakan indikasi bahwa perusahaan tidak beroperasi pada volume yang memadai bagi kapasitas investasinya. Asumsi ini didukung oleh studi yang dilakukan oleh Misran dan Chabachib (2017) juga studi Sutrisno dan Yulianeu (2015) yang menyatakan bahwa Total Asset Turnover berpengaruh positif dan signifikan terhadap Price to Book Value.

$\mathbf{H}_{4}$ :TATO berpengaruh signifikan terhadap PBV.

\section{Pengaruh ROA terhadap PBV}

Menurut Sawir (2005), Return on Assets (ROA) merupakan rasio yang digunakan untuk mengukur kemampuan manajemen perusahaan dalam memperoleh keuntungan (laba) secara keseluruhan. Semakin besar ROA suatu perusahaan, semakin besar pula tingkat keuntungan yang dicapai perusahaan dan semakin baik pula posisi perusahaan tersebut dari segi penggunaan aset. Asumsi ini didukung oleh studi yang dilakukan oleh Misran dan Chabachib (2017) juga studi oleh Novari dan Lestari (2016) yang menyatakan bahwa Return on Asset berpengaruh positif dan signifikan terhadap Price to Book Value. H5: ROA berpengaruh signifakan terhadap PBV.

\section{Pengaruh ROA dalam memediasi hubungan DER terhadap PBV}

Debt to Equity Rati (DER) menggambarkan perbandingan antara total hutang dengan total ekuitas yang dimiliki oleh perusahaan. Apabila mayoritas kegiatan operasional dalam perusahaan dibiayai oleh hutang. Maka, nilai DER dalam perusahaan tersebut tinggi. Besarnya hutang juga akan mengakibatkan penurunan pada pendapatan bersih perusahaan. Akibatnya, nilai perusahaan akan dinilai buruk oleh para calon investor, karena dengan rendahnya tingkat profitabilitas perusahaan secara otomatis akan mengakibatkan penurunan pada harga saham perusahaan. Dengan demikian Debt to Equity Ratio (DER) mempunyai pengaruh negatif terhadap Return On Asset (ROA). Debt to Equity Ratio (DER) juga mempunyai pengaruh negatif terhadap nilai perusahaan. Asumsi ini didukung oleh studi yang dilakukan Erawati dan Sukma (2014) juga studi yang dilakukan oleh Nasehah (2012). Dengan demikian dapat dirumuskan hipotesis sebagai berikut.

H6: Return On Asset (ROA) memediasi pengaruh DER terhadap PBV. 


\section{Hubungan ROA dalam memediasi hubungan TATO terhadap PBV}

TATO berpengaruh positif terhadap profitabilitas yang diukur dengan ROA sebagaimana studi yang dilakukan oleh Alivia (2013), Noor (2011), dan Sari (2013). Disamping itu TATO juga berpengaruh positif pada nilai perusahaan yang diukur dengan PBV sebagaimana studi yang dilakuan oleh Alivia (2013). Karena TATO berpengaruh positif terhadap ROA dan PBV, maka dapat dirumuskan hipotesis sebagai berikut :

H7: Return On Asset (ROA) memediasi pengaruh TATO terhadap PBV.

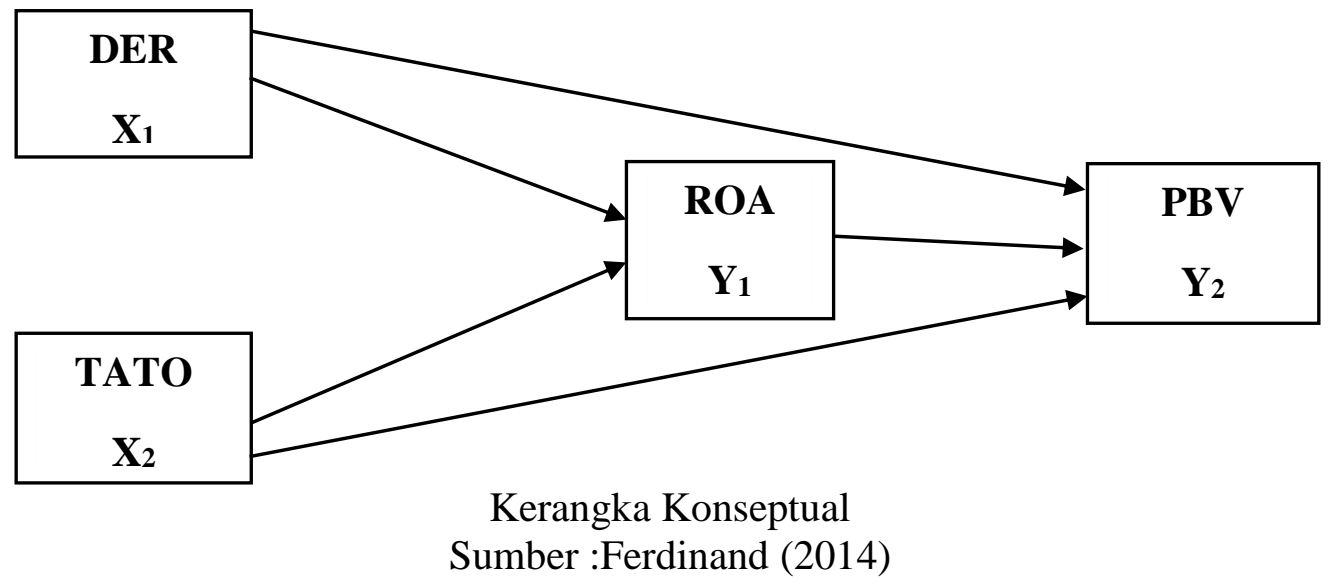

\section{METODE PENELITIAN}

Unit analisis pada studi ini dilakukan pada Perusahaan Manufaktur subsektor Pertambangan Baru Bara yang terdaftar di Bursa Efek Indonesia periode 2015-2017 melalui media internet dengan situs BEI atau www.idx.co.id. Dalam studi ini, yang akan menjadi populasi adalah Perusahaan Sektor Pertambangan Batubara yang terdaftar di Bursa Efek Indonesia Periode 2015-2017 dengan populasi sebanyak 24 Perusahaan Sektor Pertambangan Batu Bara. Sampel yang diteliti sebanyak 9 Perusahaan Pertambangan Batu Bara yang terdaftar di Bursa Efek Indonesia. Teknik sampling yang digunakan adalah teknik purposive sampling. Data studi yang digunakan adalah data sekunder. Data yang diperoleh dari website Bursa Efek Indonesia atau BEI (www.idx.co.id, www.sahamok.com) dan website masing-masing perusahaan untuk periode 2015-2017, dan sumber-sumber lain melalui buku, jurnal, dan hasil penlitian yang berhubungan dengan studi ini. Setelah data terkumpul, kemudian dianalisis melalui analisis jalur untuk diketahui pengaruh langsung dan tidak langsungnya dari variabel laten independen terhadap dependen, namun sebelum itu semua data diuji terlebih dahulu untuk asumsi klasiknya. 


\section{HASIL DAN PEMBAHASAN}

\section{Analisis Jalur (Path Analysis)}

Analisis jalur digunakan untuk melukiskan dan menguji model hubungan antara variabel yang berbentuk sebab akibat (bukan bentuk hubungan interaktif atau reciprocal), dengan demikian dalam model hubungan antar variabel tersebut, terdapat variabel independen yang dalam hal ini disebut variabel endogen (exogenous), dan variabel dependen yang disebut variabel endogen (endogenous). Sugiyono dan Susanto (2015).

Analisis jalur ini merupakan perluasan atau kepanjangan dari regresi berganda yang digunakan untuk menaksir hubungan kausalitas (sebab-akibat) antar variabel yang telah ditetapkan sebelumnya, serta menguji besarnya sumbangan atau kontribusi masingmasing variabel eksogen terhadap variabel endogen Ferdinand (2014).

\section{Hasil Analisis Data}

\section{Analisis Statistik Deskriptif}

Tabel 1. Analisis Statistik Deskriptif Descriptive Statistics

\begin{tabular}{|l|r|r|r|r|r|}
\hline & N & Minimum & Maximum & \multicolumn{1}{|c|}{ Mean } & Std. Deviation \\
\hline DER & 27 & 17 & 102 & 56.56 & 24.243 \\
TATO & 27 & 11 & 207 & 93.74 & 42.508 \\
ROA & 27 & 12 & 3649 & 1149.30 & 913.284 \\
PBV & 27 & 35 & 466 & 151.74 & 108.975 \\
Valid N (listwise) & 27 & & & & \\
\hline
\end{tabular}

Sumber : Data diolah SPSS versi 21 (2019)

Berdasarkan pada tabel di atas, penjelasan mengenai hasil pengujian statistic deskriptif diuraikan sebagai berikut :

\section{Debt to Equity Ratio (DER)}

Berdasarkan hasil Output SPSS versi 21 pada Tabel diatas dapat diketahui bahwa 9 Perusahaan Pertambangan Batu Bara selama 3 tahun diperoleh hasil nilai minimum variabel Debt to Equity Ratio (DER) sebesar 17 dan nilai maksimum Debt to Equity Ratio (DER) diperoleh hasil sebesar 102. Dengan demikian hasil tersebut menunjukkan bahwa besar nilai Debt to Equity Ratio (DER) pada Perusahaan Pertambangan Batu Bara berkisar antara 17 hingga 102. Sedangkan nilai rata-rata (mean) sebesar 56,56 dan pada standar deviasi diperoleh nilai sebesar 24,243. Karena nilai rata-rata 56,56 dan standar deviasi sebesar 24,243. Maka dapat dikatakan bahwa nilai rata-rata lebih besar dari nilai standar deviasi. 


\section{Total Asset Turnover (TATO)}

Berdasarkan hasil Output SPSS versi 21 pada Tabel diatas dapat diketahui bahwa 9 Perusahaan Pertambangan Batu Bara selama 3 tahun berturut-turut diperoleh hasil nilai minimum variabel Total Asset Turnover (TATO) sebesar 11 dan nilai maksimum Total Asset Turnover (TATO) diperoleh hasil sebesar 207 Dengan demikian hasil tersebut menunjukkan bahwa besar nilai Total Asset Turnover (TATO) pada Perusahaan Pertambangan Batu Bara berkisar antara 11 hingga 207. Sedangkan nilai rata-rata (mean) sebesar 93,74 dan pada standar deviasi diperoleh nilai sebesar 42,508. Karena nilai ratarata 93,74 dan standar deviasi sebesar 42,508. Maka dapat dikatakan bahwa nilai rata-rata lebih besar dari nilai standar deviasi.

\section{Return on Asset (ROA)}

Berdasarkan hasil output SPSS versi 21 pada Tabel diatas dapat diketahui bahwa 9 Perusahaan Pertambangan Batu Bara selama 3 tahun diperoleh hasil nilai minimum variabel Return on Asset (ROA) sebesar 12 dan nilai maksimum Return on Asset (ROA) diperoleh hasil sebesar 3649. Dengan demikian hasil tersebut menunjukkan bahwa besar nilai Return on Asset (ROA) pada perusahaan pertambangan batu bara berkisar antara 12 hingga 3649. Sedangkan nilai rata-rata (mean) sebesar 34,4789 dan pada standar deviasi diperoleh nilai sebesar 1149,30. Karena nilai rata-rata 1149,30 dan standar deviasi sebesar 913,284. Maka dapat dikatakan bahwa nilai rata-rata lebih besar dari nilai standar deviasi.

\section{Price to Book Value (PBV)}

Berdasarkan hasil output SPSS versi 21 pada Tabel diatas dapat diketahui bahwa 9 Perusahaan Pertambangan Batu Bara selama 3 tahun studi diperoleh hasil nilai minimum variabel Price to Book Value (PBV) sebesar 35 dan nilai maksimum Price to Book Value (PBV) diperoleh hasil sebesar 466. Dengan demikian hasil tersebut menunjukkan bahwa besar nilai Price to Book Value (PBV) pada Perusahaan Pertambangan Batu Bara berkisar antara 35 hingga 466. Sedangkan nilai rata-rata (mean) sebesar 151,74 dan pada standar deviasi diperoleh nilai sebesar 108,975. Karena nilai rata-rata 151,74 dan standar deviasi sebesar 108,975. Maka dapat dikatakan bahwa nilai rata-rata lebih besar dari nilai standar deviasi.

\section{Uji Normalitas}

Uji Normalitas adalah sebuah uji yang dilakukan dengan tujuan untuk menilai sebaran data pada sebuah kelompok data atau variabel, apakah sebaran data tersebut berdistribusi normal atau tidak. 
Tabel 2. Uji Normalitas

One-Sample Kolmogorov-Smirnov Test

\begin{tabular}{|ll|r|r|r|r|}
\hline & & \multicolumn{1}{|c|}{ DER } & \multicolumn{1}{c|}{ TATO } & \multicolumn{1}{c|}{ ROA } & \multicolumn{1}{c|}{ PBV } \\
\hline N & & 27 & 27 & 27 & 27 \\
Normal Parameters ${ }^{\mathrm{a}, \mathrm{b}}$ & Mean & 56.56 & 93.74 & 1149.30 & 151.74 \\
& Std. Deviation & 24.243 & 42.508 & 913.284 & 108.975 \\
& & & & & \\
Most Extreme Differences & Absolute & .133 & .136 & .147 & .183 \\
& Positive & .119 & .136 & .147 & .183 \\
Kolmogorov-Smirnov Z & Negative & -.133 & -.066 & -.107 & -.142 \\
Asymp. Sig. (2-tailed) & & .691 & .706 & .765 & .953 \\
\end{tabular}

a. Test distribution is Normal.

b. Calculated from data.

Berdasarkan hasil Output SPSS versi 21 pada Tabel diatas syarat yang digunakan dalam pengambilan keputusan untuk dapat menentukan normal tidaknya distribusi data yang sedang di uji ialah dengan mengacu pada nilai "Asymp.Sig". Jika nilai Asymp.Sig lebih besar dari 0,05, maka dapat disimpulkan bahwa data yang di uji berdistribusi normal. Dan sebaliknya, apabila nilai Asymp.Sig lebih kecil dari 0,05, maka dapat disimpulkan bahwa data yang diuji berdistribusi tidak normal. Berdasarkan dari hasil uji normalitas yang telah dilakukan pada empat variabel diperoleh hasil nilai Asymp. SigDER sebesar 0,726, sedangkan nilai TATO sebesar0,701, untuk nilai ROA sebesar 0,602 dan nilai PBV sebesar0,324 dan semua variabel tersebut memiliki nilai lebih besar 0,05. Dengan demikian, dapat disimpulkan bahwa data studi berdistribusi normal.

\section{Analisis Jalur (Path Analysis)}

Model ini telah memenuhi persyaratan analisis jalur yang berdistribusi normal. sesuai dengan kerangka konseptual, maka persamaan struktual yang dibuat adalah:

$\mathrm{Y} 1=\rho \mathrm{Y}_{1} \mathrm{X}_{1}+\rho \mathrm{Y}_{1} \mathrm{X}_{2}+\mathrm{e} 1$ (Sebagai Sktruktual Model I)

$\mathrm{Y} 2=\rho \mathrm{Y}_{2} \mathrm{X}_{1}+\rho \mathrm{Y}_{2} \mathrm{X}_{2}+\mathrm{e} 2($ Sebagai Struktual Model II)

$\mathrm{Y} 2=\rho \mathrm{Y}_{2} \mathrm{X}_{1}+\rho \mathrm{Y}_{2} \mathrm{X}_{2}+\rho \mathrm{Y}_{2} \mathrm{Y}_{1}+\mathrm{e} 3$ (Sebagai Struktual Model III)

Tabel 3. Analisis Jalur Model I

Coefficients ${ }^{\mathrm{a}}$

\begin{tabular}{|c|c|c|c|c|c|}
\hline \multirow[t]{2}{*}{ Model } & \multicolumn{2}{|c|}{ Unstandardized Coefficients } & \multirow{2}{*}{$\begin{array}{c}\begin{array}{c}\text { Standardized } \\
\text { Coefficients }\end{array} \\
\text { Beta }\end{array}$} & \multirow[t]{2}{*}{$\mathrm{T}$} & \multirow[t]{2}{*}{ Sig. } \\
\hline & B & Std. Error & & & \\
\hline (Constant) & -169.149 & 536.633 & & -.315 & .755 \\
\hline DER & -.898 & 5.857 & -.024 & -.153 & .879 \\
\hline TATO & 14.606 & 3.340 & .680 & 4.373 & .000 \\
\hline
\end{tabular}

a. Dependent Variable: ROA

Sumber : Data SPSS versi 21 
IMKA Implementasi Manajemen \& Kewirausahaan - April, Vol. 1, No. 1, 1-19, 2021

\begin{tabular}{|l|r|r|r|c|}
\hline Model & \multicolumn{1}{|c|}{$\mathrm{R}$} & R Square & $\begin{array}{c}\text { Adjusted R } \\
\text { Square }\end{array}$ & $\begin{array}{c}\text { Std. Error of the } \\
\text { Estimate }\end{array}$ \\
\hline 1 & $.687^{\mathrm{a}}$ & .473 & .429 & 690.376 \\
\hline
\end{tabular}

a. Predictors: (Constant), TATO, DER

Sumber : Data SPSS versi 21

\section{Analisis Jalur Model 1}

1. Berdasarkan hasil Output SPSS versi 21 padaAnalisis Jalur Model 1 pada bagian tabel "Coefficients" dapat diketahui bahwa nilai signifikansi dua variabel yaitu DER sebesar 0,879 dan TATO sebesar 0,000. Dengan demikian nilai DER lebih besar dari 0,05 , sedangkan nilai TATO lebih kecil dari 0,05. Sehingga dapat disimpulkan bahwa Analisis Jalur Model 1, yakni variabel DER berpengaruh tidak signifikan terhadap ROA sedangkan variabel TATO berpengaruhsignifikan terhadap ROA.

2. Besarnya nilai Adjusted R Square yang terdapat pada tabel "ModelSummary" adalah sebesar 0,429. Hal ini menunjukkan bahwa besarnya pengaruh DERdan TATO terhadap ROA adalah sebesar 42,9\% sementara sisanya 57,1\% merupakan kontribusi dari variabel-variabel lain yang tidak dimasukkan dalam penelitian. Sementara itu, untuk nilai e1 dapat dicari dengan rumus e $1=\sqrt{(1-0,429)}=0,756$.

Tabel 4. Analisis Jalur Model II Coefficients ${ }^{\mathbf{a}}$

\begin{tabular}{|c|c|c|c|c|c|}
\hline \multirow[t]{2}{*}{ Model } & \multicolumn{2}{|c|}{ Unstandardized Coefficients } & \multirow{2}{*}{$\begin{array}{c}\text { Standardized } \\
\text { Coefficients } \\
\text { Beta }\end{array}$} & \multirow[t]{2}{*}{$\mathrm{T}$} & \multirow[t]{2}{*}{ Sig. } \\
\hline & $\mathrm{B}$ & Std. Error & & & \\
\hline (Constant) & 26.202 & 82.071 & & .319 & .752 \\
\hline DER & .593 & .896 & .132 & .662 & .514 \\
\hline TATO & .981 & .511 & .383 & 1.921 & .067 \\
\hline
\end{tabular}

a. Dependent Variable: PBV

Sumber : Data SPSS versi 21

Model Summary

\begin{tabular}{|l|l|l|l|l|}
\hline Model & $\mathrm{R}$ & R Square & $\begin{array}{l}\text { Adjusted R } \\
\text { Square }\end{array}$ & $\begin{array}{l}\text { Std. Error of the } \\
\text { Estimate }\end{array}$ \\
\hline 1 & $.365^{\mathrm{a}}$ & .133 & .061 & 105.584 \\
\hline
\end{tabular}

a. Predictors: (Constant), TATO, DER

Sumber : Data SPSS versi 21

\section{Analisis Jalur Model II}

1. Berdasarkan hasil Output SPSS versi 21 padaAnalisis Jalur Model II pada bagian tabel "Coefficients", diketahui bahwa nilai signifikansi dari dua variabel yaitu DER sebesar 0,514, dan TATO sebesar 0,067 lebih besar dari 0,05. Hasil ini memberi 
kesimpulan bahwa Analisis Jalur Model II yakni variabel DER dan TATO berpengaruh tidak signifikan terhadap PBV.

2. Besarnya nilai Adjusted R Square yang terdapat pada tabel "Model Summary" adalah sebesar 0,061. Hal ini menunjukkan bahwa kontribusi DER dan TATO terhadap PBV adalah sebesar 61\% sementara sisanya 39\% merupakan kontribusi dari variabel-variabel lain yang tidak diteliti. Sementara untuk nilai $\mathrm{e} 2=\sqrt{(1-0,061)}=0,969$.

Tabel 5. Analisis Jalur Model III Coefficients $^{\mathrm{a}}$

\begin{tabular}{|l|r|r|r|r|r|}
\hline \multirow{2}{*}{ Model } & \multicolumn{2}{|c|}{ Unstandardized Coefficients } & \multicolumn{1}{c|}{$\begin{array}{l}\text { Standardized } \\
\text { Coefficients }\end{array}$} & \multicolumn{1}{c|}{ T } & \multirow{2}{*}{ Sig. } \\
\cline { 2 - 4 } & \multicolumn{1}{|c|}{$\mathrm{B}$} & \multicolumn{1}{c|}{ Std. Error } & \multicolumn{1}{c|}{ Beta } & & \\
\hline \multirow{2}{*}{ (Constant) } & 32.163 & 81.749 & & .393 & .698 \\
1 & & & & & \\
DER & .625 & .891 & .139 & .702 & .490 \\
TATO & .466 & .681 & .182 & .685 & .500 \\
ROA & .035 & .031 & .295 & 1.136 & .268 \\
\hline
\end{tabular}

a. Dependent Variable: PBV

Sumber : Data diolah SPSS versi 21

Model Summary

\begin{tabular}{|l|r|r|r|c|}
\hline Model & \multicolumn{1}{|c|}{$\mathrm{R}$} & R Square & $\begin{array}{c}\text { Adjusted R } \\
\text { Square }\end{array}$ & $\begin{array}{c}\text { Std. Error of the } \\
\text { Estimate }\end{array}$ \\
\hline 1 & $.424^{\mathrm{a}}$ & .179 & .072 & 104.952 \\
\hline
\end{tabular}

a. Predictors: (Constant), ROA, DER, TATO

Sumber : Data diolah versi 21

\section{Analisis Jalur Model III}

1. Berdasarkan hasil Output SPSS versi 21 pada Analisis Jalur Model III pada bagian tabel "Coefficients", diketahui bahwa nilai signifikansi dari ketiga variabel yaitu DER sebesar 0,490, TATO sebesar 0,500 dan ROA sebesar 0,268 lebih besar dari 0,05. Hasil ini memberi kesimpulan bahwa Analisis Jalur Model III , yakni variabel DER, TATO dan ROA berpengaruh tidak signifikan terhadap PBV.

2. Besarnya nilai Adjusted R Square yang terdapat pada table "Model Summary" adalah sebesar 0,072. Hal ini menunjukkan bahwa kontribusi DER, TATO, dan ROA terhadap PBV adalah sebesar $72 \%$ sementara sisanya $28 \%$ merupakan kontribusi dari variabel-variabel lain yang tidak diteliti. Sementara untuk nilai e3 $=\sqrt{(1-0,072)}=0,963$.

\section{Uji F (Simultan)}

Uji F dikenal dengan uji serentak atau Uji Model / Uji Anova, yaitu uji untuk melihat bagaimanakah pengaruh semua variabel bebasnya secara bersama-sama terhadap variabel terikatnya. 
IMKA Implementasi Manajemen \& Kewirausahaan - April, Vol. 1, No. 1, 1-19, 2021

Tabel 6. Uji F (Simultan) Model I

ANOVA ${ }^{\mathrm{a}}$

\begin{tabular}{|rl|r|r|r|r|r|}
\hline Model & & Sum of Squares & df & Mean Square & F & Sig. \\
\hline \multirow{3}{*}{1} & Regression & 1222.133 & 2 & 611.066 & 15.495 & $.000^{\mathrm{b}}$ \\
& Residual & 946.493 & 24 & 39.437 & & \\
& Total & 2168.626 & 26 & & & \\
\hline
\end{tabular}

a. Dependent Variable: ROA

b. Predictors: (Constant), TATO, DER

Sumber : Data diolah SPSS versi 21

Berdasarkan hasil Output SPSS versi 21 pada tabel 4.10 di atas, diketahui nilai signifikansi (Sig.) adalah sebesar 0,000. Karena nilai signifikan 0,000 lebih kecil dari 0,05, maka sebagaimana dasar pengambilan keputusan dalam uji $\mathrm{F}$ dapat disimpulkan bahwa hipotesis diterima atau dengan kata lain variabel DER $\left(\mathrm{X}_{1}\right)$ dan TATO $\left(\mathrm{X}_{2}\right)$ secara simultan berpengaruhsignifikan terhadap variabel ROA $\left(\mathrm{Y}_{1}\right)$.

Tabel 7. Uji F (Simultan) Model II ANOVA ${ }^{a}$

\begin{tabular}{|rl|r|r|r|r|r|}
\hline Model & & Sum of Squares & Df & Mean Square & F & Sig. \\
\hline \multirow{3}{*}{1} & Regression & 3.475 & 2 & 1.737 & 1.522 & $.239^{\mathrm{b}}$ \\
& Residual & 27.402 & 24 & 1.142 & & \\
& Total & 30.876 & 26 & & & \\
\hline
\end{tabular}

a. Dependent Variable: PBV

b. Predictors: (Constant), TATO, DER

Sumber : Data diolah versi 21

Berdasarkan hasil Output SPSS versi 21 pada tabel 4.11 di atas, diketahui nilai signifikansinya (Sig.) adalah sebesar 0,239. Karena nilai signifikan 0,239 lebih besar dari 0,05, maka sebagaimana dasar pengambilan keputusan dalam uji $\mathrm{F}$ dapat disimpulkan bahwa hipotesis ditolak atau dengan kata lain variabel DER $\left(\mathrm{X}_{1}\right)$ dan TATO $\left(\mathrm{X}_{2}\right)$ secara simultan berpengaruh tidak signifikan terhadap variabel PBV $\left(\mathrm{Y}_{2}\right)$.

Tabel 8. Uji F (Simultan) Model III

ANOVA $^{\mathrm{a}}$

\begin{tabular}{|rl|r|r|r|r|r|}
\hline Model & & Sum of Squares & Df & Mean Square & F & Sig. \\
\hline \multirow{3}{*}{1} & Regression & 5.127 & 3 & 1.709 & 1.526 & $.234^{\mathrm{b}}$ \\
& Residual & 25.750 & 23 & 1.120 & & \\
& Total & 30.876 & 26 & & & \\
\hline
\end{tabular}

a. Dependent Variable: PBV

b. Predictors: (Constant), ROA, DER, TATO

Sumber : Data diolah SPSS versi 21

Berdasarkan hasil Output SPSS versi 21 pada tabel 4.12 di atas, diketahui nilai signifikansinya (Sig.) adalah sebesar 0,234. Karena nilai signifikan 0,234 lebih besar dari 0,05, maka sebagaimana dasar pengambilan keputusan dalam uji $\mathrm{F}$ dapat disimpulkan bahwa hipotesis ditolak atau dengan kata lain variabel DER $\left(\mathrm{X}_{1}\right)$, TATO $\left(\mathrm{X}_{2}\right)$ dan ROA $\left(\mathrm{Y}_{1}\right)$ secara simultan berpengaruh tidak signifikan terhadap variabel PBV $\left(\mathrm{Y}_{2}\right)$. 


\section{Uji t (Parsial)}

Uji t dikenal dengan uji parsial yaitu, untuk menguji bagaimana pengaruh masingmasing variabel bebasnya secara sendiri-sendiri terhadap variabel terikatnya.

Tabel 9. Uji t (Parsial) Model I

Coefficients ${ }^{\mathbf{a}}$

\begin{tabular}{|c|c|c|c|c|c|c|}
\hline \multirow{2}{*}{\multicolumn{2}{|c|}{ Model }} & \multicolumn{2}{|c|}{ Unstandardized Coefficients } & \multirow{2}{*}{$\begin{array}{c}\begin{array}{c}\text { Standardized } \\
\text { Coefficients }\end{array} \\
\text { Beta }\end{array}$} & \multirow[t]{2}{*}{$\mathrm{t}$} & \multirow[t]{2}{*}{ Sig. } \\
\hline & & $\mathrm{B}$ & Std. Error & & & \\
\hline \multirow{3}{*}{1} & (Constant) & -169.149 & 536.633 & & -.315 & .755 \\
\hline & DER & -.898 & 5.857 & -.024 & -.153 & .879 \\
\hline & TATO & 14.606 & 3.340 & .680 & 4.373 & .000 \\
\hline
\end{tabular}

a. Dependent Variable: ROA

Sumber : Data diolah SPSS versi 21

Berdasarkan hasil Output SPSS versi 21 pada tabel 4.13 di atas diketahui nilai signifikansi (Sig) variabel DER adalah sebesar 0,879. Karena nilai signifikan 0,879 lebih besar dari 0,05. Maka, dapat disimpulkan bahwa hipotesis ditolak. Artinya variabel DER $\left(\mathrm{X}_{1}\right)$ berpengaruh tidak signifikan terhadap variabel ROA $\left(\mathrm{Y}_{1}\right)$. Sedangkan nilai signifikansi (Sig) variabel TATO adalah sebesar 0,000 lebih kecil 0,05. Maka, dapat disimpulkan bahwa hipotesis diterima. Artinya, variabel TATO berpengaruh signifikan terhadap variabel ROA $\left(\mathrm{Y}_{1}\right)$.

Tabel 10. Uji t (Parsial) Model II Coefficients $^{\text {a }}$

\begin{tabular}{|c|c|c|c|c|c|}
\hline \multirow[t]{2}{*}{ Model } & \multicolumn{2}{|c|}{ Unstandardized Coefficients } & \multirow{2}{*}{$\begin{array}{c}\text { Standardized } \\
\text { Coefficients } \\
\text { Beta }\end{array}$} & \multirow[t]{2}{*}{$\mathrm{T}$} & \multirow[t]{2}{*}{ Sig. } \\
\hline & $\mathrm{B}$ & Std. Error & & & \\
\hline (Constant) & 26.202 & 82.071 & & .319 & .752 \\
\hline DER & .593 & .896 & .132 & .662 & .514 \\
\hline TATO & .981 & .511 & .383 & 1.921 & .067 \\
\hline
\end{tabular}

a. Dependent Variable: PBV

Sumber : Data diolah SPSS versi 21

Berdasarkan hasil Output SPSS versi 21 pada tabel 4.14 di atas diketahui nilai signifikansi (Sig.) variabel DER adalah sebesar 0,514. Karena nilai signifikan 0,514 lebih besar dari 0,05. Maka, dapat disimpulkan bahwa hipotesis ditolak. Artinya variabel DER $\left(\mathrm{X}_{1}\right)$ berpengaruh tidak signifikan terhadap variabel PBV $\left(\mathrm{Y}_{2}\right)$. Sedangkan nilai signifikansi (Sig.) variabel TATO adalah sebesar 0,067 lebih besar dari 0,05. Maka, dapat disimpulkan bahwa hipotesis ditolak. Artinya, variabel TATO berpengaruh tidak signifikan terhadap variabel PBV $\left(\mathrm{Y}_{2}\right)$. 
Tabel 11. Uji t (Parsial) Model III Coefficients ${ }^{\mathrm{a}}$

\begin{tabular}{|c|c|c|c|c|c|}
\hline \multirow[t]{2}{*}{ Model } & \multicolumn{2}{|c|}{ Unstandardized Coefficients } & \multirow{2}{*}{$\begin{array}{c}\begin{array}{c}\text { Standardized } \\
\text { Coefficients }\end{array} \\
\text { Beta }\end{array}$} & \multirow[t]{2}{*}{$\mathrm{T}$} & \multirow[t]{2}{*}{ Sig. } \\
\hline & $\mathrm{B}$ & Std. Error & & & \\
\hline (Constant) & 32.163 & 81.749 & & .393 & .698 \\
\hline 1 DER & .625 & .891 & .139 & .702 & .490 \\
\hline TATO & .466 & .681 & .182 & .685 & .500 \\
\hline ROA & .035 & .031 & .295 & 1.136 & .268 \\
\hline
\end{tabular}

a. Dependent Variable: PBV

Sumber : Data diolah SPSS versi 21

Berdasarkan hasil Output SPSS versi 21 pada tabel 4.15 di atas diketahui nilai signifikansi (Sig.) variabel DER adalah sebesar 0,490. Karena signifikan 0,490 lebih besar dari 0,05. Maka, dapat disimpulkan bahwa hipotesis ditolak. Artinya variabel DER $\left(\mathrm{X}_{1}\right)$ tidak berpengaruh signifikan terhadap variabel $\mathrm{PBV}\left(\mathrm{Y}_{2}\right)$. Sedangkan nilai signifikansi (Sig.) variabel TATO adalah sebesar 0,500. Karena nilai signifikan 0,500 lebih besar dari 0,05. Maka, dapat disimpulkan bahwa hipotesis ditolak. Artinya, variabel TATO berpengaruh tidak signifikan terhadap variabel PBV $\left(\mathrm{Y}_{2}\right)$. Dan untuk nilai signifikansi (Sig.) variabel ROA sebesar 0,268. Karena nilai signifikan 0,268 lebih besar dari 0,05. Maka, dapat disimpulkan bahwa hipotesis ketiga ditolak. Artinya, variabel ROA berpengaruh tidak signifikan terhadap variabel PBV $\left(\mathrm{Y}_{2}\right)$.

\section{Koefisien Determinasi ( $\mathrm{R}^{2}$ )}

Nilai koefisien determinasi atau Adjusted $R$ Square digunakan untuk memprediksi dan melihat seberapa besar kontribusi pengaruh yang diberikan variabel $\mathrm{X}$ secara simultan (bersama-sama) terhadap variabel Y.

Tabel 12. Koefisien Determinasi Model I

Model Summary

\begin{tabular}{|l|r|r|r|r|}
\hline Model & $\mathrm{R}$ & R Square & Adjusted R Square & Std. Error of the Estimate \\
\hline 1 & $.687^{2}$ & .473 & .429 & 690.376 \\
\hline
\end{tabular}

a. Predictors: (Constant), TATO, DER

Sumber : Data diolah SPSS versi 21

Berdasarkan hasil Output SPSS versi 21 pada tabel "Model Summary" di atas, diketahui nilai koefisien determinasi atau Adjusted $R$ Square adalah sebesar 0,429. Nilai Adjusted $R$ Square 0,429 atau sama dengan 42,9\% mengandung arti bahwa variabel DER $\left(\mathrm{X}_{1}\right)$ dan TATO $\left(\mathrm{X}_{2}\right)$ berpengaruh terhadap variabel ROA $\left(\mathrm{Y}_{1}\right)$ sebesar $42,9 \%$ sedangkan sisanya $57,1 \%$ dipengaruhi oleh variabel lain di luar persamaan regresi ini atau variabel yang tidak diteliti. 
Tabel 13. Koefisien Determinasi Model II

Model Summary

\begin{tabular}{|l|r|r|r|r|}
\hline Model & R & R Square & Adjusted R Square & Std. Error of the Estimate \\
\hline 1 & $.365^{\mathrm{a}}$ & .133 & .061 & 105.584 \\
\hline
\end{tabular}

a. Predictors: (Constant), TATO, DER

Sumber : Data diolah SPSS versi 21

Berdasarkan hasil Output SPSS versi 21 pada tabel "Model Summary" di atas, diketahui nilai koefisien determinasi atau Adjusted $R$ Square adalah sebesar 0,061. Nilai Adjusted $R$ Square 0,061 atau sama dengan $61 \%$ mengandung arti bahwa variabel DER $\left(\mathrm{X}_{1}\right)$ dan TATO $\left(\mathrm{X}_{2}\right)$ berpengaruh terhadap variabel PBV $\left(\mathrm{Y}_{2}\right)$ sebesar $61 \%$ sedangkan sisanya 39\% dipengaruhi oleh variabel lain di luar persamaan regresi ini atau variabel yang tidak diteliti.

Tabel 14. Koefisien Determinasi Model III

Model Summary

\begin{tabular}{|l|r|r|r|r|}
\hline Model & $\mathrm{R}$ & $\mathrm{R}$ Square & Adjusted R Square & Std. Error of the Estimate \\
\hline 1 & $.424^{\mathrm{a}}$ & .179 & .072 & 104.952 \\
\hline
\end{tabular}

a. Predictors: (Constant), ROA, DER, TATO

Sumber : Data diolah SPSS versi 21

Berdasarkan hasil Output SPSS versi 21 pada tabel "Model Summary" di atas, diketahui nilai koefisien determinasi atau Adjusted $R$ Square adalah sebesar 0,072. Nilai Adjusted $R$ Square 0,072 atau sama dengan $72 \%$. Angka tersebut mengandung arti bahwa variabel DER $\left(\mathrm{X}_{1}\right)$,TATO $\left(\mathrm{X}_{2}\right)$, dan ROA $\left(\mathrm{Y}_{1}\right)$ berpengaruh terhadap variabel PBV $\left(\mathrm{Y}_{2}\right)$ sebesar $72 \%$ sedangkan sisanya $28 \%$ dipengaruhi oleh variabel lain di luar persamaan regresi ini atau variabel yang tidak diteliti.

\section{PEMBAHASAN}

\section{Analisis Statistik Deskriptif}

Berdasarkan hasil studi terhadap 4 (empat) variabel yaitu, DER, TATO, ROA, dan juga PBV pada Sektor Pertambangan Batu Bara periode 2015-2017 pada nilai DER atau total hutang terhadap ekuitas perusahaan diperoleh hasil bahwa nilai total DER tertinggi terjadi pada tahun 2015. Sedangkan nilai total DER terendah terjadi pada tahun 2016. Untuk nilai total TATO atau tingkat perputaran aktiva pada suatu periode tertentu diperoleh hasil nilai total TATO tertinggi terjadi pada tahun 2016, sedangkan nilai total TATO terendah terjadi pada tahun 2015. Pada nilai ROA atau jumlah keseluruhan laba bersih total aset perusahaan diperoleh hasil nilai total ROA tertinggi terjadi pada tahun 2017, sedangkan nilai total ROA dengan tingkat terendah terjadi pada tahun 2015. Dan untuk nilai PBV atau harga buku per lembar saham perusahaan diperoleh hasil nilai PBV tertinggi terjadi pada tahun 2017, sedangkan nilai PBV terendah terjadi pada tahun 2015. 


\section{Hasil Pengujian Debt to Equity Ratio (DER) terhadap Retur On Asset (ROA)}

Pengaruh langsung variabel Debt to Equity Ratio (DER) terhadap variabel Return On Asset (ROA) diperoleh nilai koefisien sebesar -0,024 dengan nilai signifikansi sebesar 0,879 . Hal ini berarti hipotesis yang menyatakan bahwa ada pengaruh signifikan DER terhadap ROA ditolak. Hasil studi ini didukung oleh studi Utami dan Prasetiono (2016) yang menyatakan bahwa variabel DER berpengaruh negatif signifikan terhadap ROA. Bila tingkat hutang perusahaan tinggi, maka pendapatan bersih yang diterima oleh perusahaan juga akan mengalami penurunan. Akibatnya, tidak akan menarik minat para calon investor untuk menanamkan modalnya pada perusahaan. Studi ini juga didukung oleh teori dari Hery (2015) yang mendefinisikan DER merupakan rasio yang digunakan untuk mengukur besarnya proporsi hutang terhadap modal. Semakin tinggi DER maka berarti semakin kecil jumlah modal pemilik yang dapat dijadikan sebagai jaminan hutang.

\section{Hasil Pengujian Total Asset Turn Over (TATO) terhadap Return On Asset (ROA)}

Pengaruh langsung variabel Total Asset Turnover (TATO) terhadap variabel Return On Asset (ROA) diperoleh nilai koefisien sebesar 0,680 dengan nilai signifikansi sebesar 0,000 . Hal ini berarti hipotesis yang menyatakan bahwa ada pengaruh signifikan TATO terhadap ROA diterima. Hasil studi ini didukung oleh Sutrisno dan Yulianeu (2017) yang mengatakan bahwa TATO berpengaruh positif signifikan terhadap ROA. Untuk dapat mencapai nilai Return On Asset (ROA) yang tinggi maka, aset perusahaan harus memiliki tingkat perputaran yang tinggi pula. Studi ini juga didukung oleh teori dari Kasmir (2014) yang mendefinisikan Total Asset Turnover (TATO) adalah rasio pengelolaan aktiva terakhir mengukur perputaran seluruh aset perusahaan, dan dihitung dengan membagi penjualan dengan total aset dan mengukur berapa jumlah yang diperoleh dari tiap rupiah aktiva. Apabila perusahaan menghasilkan volume usaha yang cukup untuk ukuran investasi sebesar total aktivanya, maka penjualan harus ditingkatkan.

\section{Hasil Pengujian Debt to Equity Ratio (DER) terhadap Price to Book Value (PBV)}

Pengaruh langsung variabel Debt to Equity Ratio (DER) terhadap variabel Price to Book Value (PBV) diperoleh nilai koefisien sebesar 0,132 dengan nilai signifikansi sebesar 0,514 . Hal ini berarti hipotesis yang menyatakan bahwa ada pengaruh signifikan DER terhadap PBV ditolak. Hasil studi ini didukung oleh studi Novari dan Lestari (2016) yang menyatakan bahwa leverage yang diukur dengan DER tidak berpengaruh terhadap nilai perusahaan (PBV). Untuk dapat mencapai nilai PBV yang tinggi maka, tingkat DER dalam perusahaan harus rendah. Sehingga, mayoritas kegiatan operasional dalam perusahaan lebih banyak dibiayai oleh modal sendiri. Dengan nilai DER yang rendah 
secara otomatis juga akan berpengaruh pada tingkat profitabilitas perusahaan. Hal ini mengakibatkan harga saham perusahaan juga akan mengalami peningkatan. Dengan demikian, akan banyak para calon investor yang akan tertarik untuk menanamkan modalnya.Studi ini juga didukung oleh teori dari Sartono (2010) mendefinisikan Debt to Equity Ratio (DER) merupakan imbangan antara hutang yang dimiliki perusahaan dengan modal sendiri. Semakin tinggi rasio ini berarti modal sendiri semakin sedikit dengan hutangnya.

\section{Hasil Pengujian Total Asset Turn Over (TATO) terhadap Price to Book Value (PBV)}

Pengaruh langsung variabel Total Asset Turnover (TATO) terhadap variabel Price to Book Value(PBV)diperoleh nilai koefisien sebesar 0,383 dengan nilai signifikansi sebesar 0,067 . Hal ini berarti hipotesis yang menyatakan bahwa ada pengaruh signifikan TATO terhadap PBV ditolak. Hasil studi ini didukung oleh studi Misran dan Chabachib (2017) yang menyatakan Total Asset Turnover (TATO) berpengaruh positif dan tidak signifikan terhadap Price to Book Value (PBV). Tingkat peputaran aktiva yang rendah tidak akan mampu meningkatkan pendapatan perusahaan. Rendahnya tingkat profitabilitas akan mempengaruhi harga saham perusahaan. Semakin rendah harga saham, semakin rendah pula tingkat kepercayaan para calon investor terhadap prospek perusahaan dimasa mendatang.Studi ini juga didukung oleh teori dari Syamsuddin (2011) yang mendefinisiskan Total Asset Turnover (TATO) adalah tingkat efisiensi penggunaan keseluruhan aktiva perusahaan didalam menghasilkan volume penjualan tertentu. Semakin tinggi rasio Total Asset Turnover (TATO) berarti semakin efisien penggunaan seluruh aktiva didalam menghasilkan penjualan.

\section{Hasil Pengujian Return On Asset (ROA) terhadap Price to Book Value (PBV)}

Pengaruh langsung variabel Return On Asset (ROA) terhadap variabel Price to Book Value (PBV) diperoleh nilai koefisien sebesar 0,295 dengan nilai signifikansi sebesar 0,268. Hal ini berarti hipotesis yang menyatakan bahwa ada pengaruh signifikan Return On Asset (ROA) terhadap Price to Book Value (PBV) ditolak. Hasil studi ini didukung oleh studi Sondakh.,et al (2019) yang menyatakan bahwa secara parsial ROA tidak berpengaruh signifikan terhadap nilai perusahaan PBV. Semakin tinggi nilai ROA dalam perusahaan tidak mampu menentukan bahwa nilai perusahaan itu baik dimata para investor. Karena untuk mengambil keputusan dalam menanamkan modal pada sebuah perusahaan para calon investor juga memperhatikan faktor-faktor lain seperti kondisi ekonomi, sosial, politik, volume transaksi, kondisi bursa, tingkat inflasi, dan masih banyak yang lainnya.Studi ini juga didukung oleh teori dari Kasmir (2014) yang mendefinisiskan Return On Asset (ROA) merupakan rasio yang menunjukkan hasil atas jumlah aktiva yang digunakan dalam perusahaan. 


\section{Hasil Pengujian ROA dalam memediasi hubungan DER terhadap PBV.}

Diketahui pengaruh langsung yang diberikan oleh DER $\left(\mathrm{X}_{1}\right)$ terhadap PBV $\left(\mathrm{Y}_{2}\right)$ sebesar 0,132. Sedangkan pengaruh tidak langsung DER $\left(\mathrm{X}_{1}\right)$ terhadap $\mathrm{PBV}\left(\mathrm{Y}_{2}\right)$ melalui ROA ( $\left.\mathrm{Y}_{1}\right)$ adalah perkalian antara nilai beta DER $\left(\mathrm{X}_{1}\right)$ terhadap ROA $\left(\mathrm{Y}_{1}\right)$ dengan nilai beta ROA $\left(\mathrm{Y}_{1}\right)$ terhadap PBV $\left(\mathrm{Y}_{2}\right)$ yaitu : $(-0,024) \mathrm{X}$ 0,295 = -0,008. Dan pengaruh total yang diberikan DER $\left(\mathrm{X}_{1}\right)$ terhadap PBV $\left(\mathrm{Y}_{2}\right)$ adalah pengaruh langsung ditambah dengan pengaruh tidak langsung, yaitu : 0,132 $+(-0,008)=0,124$. Berdasarkan hasil perhitungan diatas dapat diketahui bahwa nilai pengaruh langsung sebesar 0,132 dan pengaruh tidak langsung sebesar 0,124 yang berarti bahwa pengaruh tidak langsung lebih kecil dibandingkan dengan pengaruh langsung. Hal ini menunjukkan bahwa secara tidak langsung variabel DER $\left(\mathrm{X}_{1}\right)$ berpengaruh tidak signifikan terhadap variabel PBV $\left(\mathrm{Y}_{2}\right)$ melalui variabel ROA $\left(\mathrm{Y}_{1}\right)$. Hal ini berarti hipotesis yang menyatakan ada pengaruh Debt to Equity Ratio (DER) terhadap Price to Book Value (PBV) ditolak. Sehingga dapat disimpulkan bahwa Return On Asset (ROA) tidak dapat memediasi hubungan antara Debt to Equity Ratio (DER) terhadap Price to Book Value (PBV). Hasil studi ini didukung oleh studi Misran dan Chabachib (2017) yang menyatakan bahwa ROA tidak dapat memediasi hubungan antara Debt to Equity Ratio dan Price to Book Value.

\section{Hasil pengujia ROA dalam memediasi hubungan TATO terhadap PBV.}

Diketahui pengaruh langsung yang diberikan oleh TATO $\left(\mathrm{X}_{2}\right)$ terhadap PBV $\left(\mathrm{Y}_{2}\right)$ sebesar 0,383. Sedangkan pengaruh tidak langsung TATO $\left(\mathrm{X}_{2}\right)$ terhadap $\operatorname{PBV}\left(\mathrm{Y}_{2}\right)$ melalui ROA $\left(\mathrm{Y}_{1}\right)$ adalah perkalian antara nilai beta TATO $\left(\mathrm{X}_{2}\right)$ terhadap ROA $\left(\mathrm{Y}_{1}\right)$ dengan nilai beta ROA $\left(\mathrm{Y}_{1}\right)$ terhadap PBV $\left(\mathrm{Y}_{2}\right)$ yaitu : 0,680 X 0,295 = 0,206. Dan pengaruh total yang diberikan TATO $\left(\mathrm{X}_{2}\right)$ terhadap PBV $\left(\mathrm{Y}_{2}\right)$ adalah pengaruh langsung ditambah dengan pengaruh tidak langsung, yaitu : 0,383 +0,206 =0,589. Berdasarkan hasil perhitungan diatas dapat diketahui bahwa nilai pengaruh langsung sebesar 0,383 dan pengaruh tidak langsung sebesar 0,589 yang berarti bahwa pengaruh tidak langsung lebih besar dibandingkan dengan pengaruh langsung. Hal ini menunjukkan bahwa secara tidak langsung variabel TATO $\left(\mathrm{X}_{2}\right)$ berpengaruh signifikan terhadap variabel PBV $\left(\mathrm{Y}_{2}\right)$ melalui variabel ROA $\left(\mathrm{Y}_{1}\right)$. Hal ini berarti hipotesis yang menyatakan ada pengaruh Total Asset Turnover (TATO) terhadap Price to Book Value (PBV) diterima. Sehingga dapat disimpulkan bahwa Return On Asset (ROA) dapat memediasi hubungan antara Total Asset Turnover (TATO) terhadap Price to Book Value (PBV). Hasil studi ini didukung oleh studi Utami dan Prasetiono (2016) yang menyatakan bahwa ROA memediasi pengaruhTATO terhadap PBV. 


\section{KESIMPULAN}

Berdasarkan hasil studi yang telah dijelaskan di atas, maka simpulan pada hasil studi ini adalah hasil kinerja Sektor Pertambangan Batu Bara pada tahun 2017 pada nilai Return On Asset (ROA) mengalami peningkatan, sedangkan nilai Debt to Equity Ratio (DER), Total Asset Turnover (TATO), dan Price to Book Value (PBV) mengalami penurunan bila dibandingkan dengan tahun sebelumnya. Pada hasil studi ini juga menunjukkan bahwa Debt to Equity Ratio (DER) berpengaruh tidak signifikan terhadap Return On Asset (ROA). Total Asset Turnover (TATO) berpengaruh signifikan terhadap Return On Asset (ROA). Debt to Equity Ratio (DER) berpengaruh tidak signifikan terhadap Price to Book Value (PBV) pada Sektor Pertambangan Batu Bara Periode 20152017. Total Asset Turnover (TATO) berpengaruh tidak signifikan terhadap Price to Book Value (PBV). Return On Asset (ROA) berpengaruh tidak signifikan terhadap Price to Book Value (PBV). Selain itu, Return On Asset (ROA) tidak mampu memediasi hubungan antara Debt to Equity Ratio (DER) terhadap Price to Book Value (PBV). Sedangkan, Return On Asset (ROA) dapat memediasi hubungan antara Total Asset Turnover (TATO) terhadap Price to Book Value (PBV) pada Sektor Pertambangan Batu Bara Periode 20152017.

\section{DAFTAR PUSTAKA}

Astutik Dwi. (2017). Pengaruh Aktivitas Rasio Keuangan Terhadap Nilai Perusahaan (Studi Pada Industri Manufaktur). Jurnal STIE Semarang, VOL 9 No. 1 .

Brigham, Eugene F dan Houston Joel F. (2010). Dasar-dasar Manajemen Keuangan Buku 1 (edisi II). Jakarta: Salemba Empat.

Dewi Dian Masita. (2016). Pengaruh Likuiditas, Leverage, Ukuran Perusahaan Terhadap Kebijakan Dividen Tunai Dengan Profitabilitas Sebagai Variabel Intervening.Jurnal Bisnis dan Ekonomi (JBE), Vol. 23, No. 1. Hal. 12 - 19 .

Fahmi, Irham. (2014). Manajemen Keuangan Perusahaan dan Pasar Modal. Jakarta: Mitra Wacana Media.

Freeman, R.E, And Reed. (1983). Stockholder dan Stakeholder.A New PerpectiveOn Corporate Govermence.

Harmono. (2015). Manajemen Keuangan Berbasis Balanced. Jakarta: PT. Bumi Angkasa Raya.

Hemastuti, C. P. (2014). Pengaruh Profitabilitas, Kebijakan Dividen, Kebijakan Hutang, Keputusan InvestasiDan Kepemilikan InsiderTerhadap Nilai Perusahaan. Jurnal Ilmu dan Riset Akuntansi, Hal. 1-15.

Hermuningsih, S. (2013). Pengaruh Profitabilitas, Growth Opportunity, Struktur ModalTerhadap Nilai Perusahaan Pada Perusahaan Publik Di Indonesia. Bulletin Of Monetary Economics And Banking , 127-148.

Hery. (2015). Analisis Laporan Keuangan, Edisi 1. Yogyakarta: Center For Academic Publishing Services.

Kasmir. (2014). Analisis Laporan Keuangan. Jakarta: PT. Raja Grafindo Persada. 
Novari dan Lestari. (2016). Pengaruh Ukuran Perusahaan, Leverage, Dan Profitabilitas Terhadap Nilai Perusahaan Pada Sektor Properti dan Real Estate . E-Jurnal Manajemen Unud, Vol. 5, No.9,5671-5694 .

Pratama dan Wiksuana. (2016). Pengaruh Ukuran Perusahaan dan Leverage Terhadap Nilai Perusahaan Dengan Profitabilitas Sebagai Variabel Mediasi . E-Jurnal Manajemen Unud, Vol. 5, No. 2, 1338-1367 .

Rinnaya et.al. (2016). Pengaruh Profitabilitas, Rasio Aktivitas, Keputusan Pendanaan, Keputusan Investasi Terhadap Nilai Perusahaan (Studi Empiris Pada Perusahaan Manufaktur Yang Terdaftar Di BEI Tahun 2010-2014) . Journal Of Accounting, Volume 2 No.2.

Satriya dan Wahyudi. (2017). Analisis Faktor-Faktor Yang Mempengaruhi Nilai Perusahaan Manufaktur Dengan ROA Sebagai Variabel Interverning (Studi pada Perusahaan Manufaktur food and beverages yang Listed di BEI tahun 20102012). Diponegoro Journal of Management, Volume 6, Nomo 3, Halaman 1-14

Shil, N.C. (1997), Performance measures: An application of economic value added. International Journal of Business and Management, 4(3), 169-177.

Smithers dan Wright. (2007). Valuing Wall Street. Mc Graw Hill.

Sudiani dan Darmayanti. (2016). Pengaruh Profitabilitas, Likuiditas, Pertumbuhan, Dan Investment Opportunity Set Terhadap Nilai Perusahaan. E-Jurnal Manajemen Unud, Vol. 5, No.7, Hal 4545-4547.

Sugiono, Arief dan Edi. (2016). Panduan Praktis Dasar Analisa Laporan Keuangan. Jakarta: PT. Gramedia.

Sugiyono dan Susanto. (2015). Metode Penelitan Kuantitatif Kualitatif dan $R \& D$. Bandung: CV. Alfabeta.

Suwardika dan Mustanda. (2017). Pengaruh Leverage, Ukuran Perusahaan, Pertumbuhan Perusahaan, Dan Profitabilitas Terhadap Nilai Perusahaan Pada Perusahaan Properti.E-Jurnal Manajemen Unud, Vol. 6, No. 3, 1248-1277 .

Syardiana, G., Rodoni, A., Putri, Z. E. (2015). Pengaruh investment opportunity set, struktur modal, pertumbuhan perusahaan, dan return on asset terhadap nilai perusahaan. Akuntabilitas, 8(1), 39-46.

Thakur, R., Workman, L. (2016), Customer portfolio management (CPM) for improved customer relationship management (CRM): Are your customers platinum, gold, silver, or bronze?. Journal of Business Research, 69(10), 4095-4102

Utami dan Prasetiono. (2016). Analisis Pengaruh TATO, WCTO, DAN DER Terhadap Nilai Perusahaan Dengan ROA Sebagai Variabel Intervening (Studi pada Perusahaan Manufaktur yang Terdaftar di Bursa Efek Indonesia Periode Tahun 2009-2013). Jurnal Studi Manajemen \& Organisasi 13, 28-43 .

Wiyono, Gendro dan Kusuma, Hadri. (2017). Manajemen Keuangan Lanjutan Berbasis Corporate Value Creation Edisi kesatu. Yogyakarta: UPP STIM YKPN.

Sumber Tambahan :

www.ceritabumi.com

Http://www.pwc.com

www.idx.co.id

www.sahamok.com 